\title{
Stability-indicating liquid chromatographic and UV spectrophotometric methods for the quantification of ciprofibrate in capsules and tablets
}

\author{
Fernanda Macke Hellwig, Rafael Henrique Dias Reis, Suzana Del Rosso Barbosa, Marcelo Donadel \\ Malesuik* $^{*}$
}

School of Pharmacy, Federal University of Pampa, UNIPAMPA, Uruguaiana, RS, Brazil

\begin{abstract}
This study describes the development and evaluation of stability-indicating liquid chromatographic (LC) and UV spectrophotometric methods for the quantification of ciprofibrate (CPF) in tablets and capsules. Isocratic LC separation was achieved on a $\mathrm{RP}_{18}$ column using a mobile phase of $o$-phosphoric acid $(0.1 \% \mathrm{v} / \mathrm{v})$, adjusted to $\mathrm{pH} 3.0$ with triethylamine $(10 \% \mathrm{v} / \mathrm{v})$ and acetonitrile $(35: 65 \mathrm{v} / \mathrm{v})$, with a flow rate of $1.0 \mathrm{~mL} \mathrm{~min}^{-1}$. Detection was achieved with a photodiode array detector at $233 \mathrm{~nm}$. For the spectrophotometric analysis, ethanol and water were used as the solvent and a wavelength of $233 \mathrm{~nm}$ was selected for the detection. The methods were validated according to International Conference on Harmonization ( $\mathrm{ICH})$ guidelines for validating analytical procedures. Statistical analysis showed no significant difference between the results obtained by the two methods. The proposed methods were successfully applied to the CPF quality-control analysis of tablets and capsules.
\end{abstract}

Uniterms: Ciprofibrate/tablets/quality control. Ciprofibrate/capsules/quality control. UV Spectrophotometry/quantitative analysis. Liquid chromatography/stability study. Medicines/quality control.

Este estudo descreve o desenvolvimento e avaliação de método indicativo da estabilidade por cromatografia líquida (LC) e método por espectrofotometria UV para quantificação de ciprofibrato $(\mathrm{CPF})$ em comprimidos e cápsulas. No método por cromatografia líquida as análises foram realizadas isocraticamente em coluna de fase reversa $\mathrm{C} 18$, utilizando fase móvel composta por ácido $o$-fosfórico $(0.1 \% \mathrm{v} / \mathrm{v}) \mathrm{pH} 3.0$, ajustado com trietilamina $(10 \% \mathrm{v} / \mathrm{v})$, e acetonitrila $(35: 65 \mathrm{v} / \mathrm{v})$, com fluxo de $1,0 \mathrm{~mL}$ $\min ^{-1}$. A detecção foi realizada em detector de arranjo de diodos a $233 \mathrm{~nm}$. Na análise espectrofotométrica, etanol e água foram utilizados como solventes e o comprimento de onda de $233 \mathrm{~nm}$ foi selecionado para a detecção do fármaco. Os métodos foram validados de acordo com as diretrizes do International Conference on Harmonization (ICH). A análise estatística não mostrou diferença significativa entre os resultados obtidos pelos dois métodos. Os métodos foram aplicados com sucesso para análises de controle de qualidade do ciprofibrato em comprimidos e cápsulas.

Unitermos: Ciprofibrato/comprimidos/controle de qualidade. Ciprofibrato/cápsulas/controle de qualidade. Espectrofotometria UV/análise quantitativa. Cromatografia líquida/estudo da estabilidade. Medicamentos/ controle de qualidade.

\section{INTRODUCTION}

Ciprofibrate (CPF, Figure 1) is a hypolipidemic drug that is widely used to treat hypertriglyceridemia.

\footnotetext{
*Correspondence: M. D. Malesuik. Faculdade de Farmácia, Universidade Federal do Pampa - UNIPAMPA, BR 472 - Km 592, Caixa Postal 118, 97500970 - Uruguaiana - RS, Brasil. E-mail: marcelodonadel@gmail.com
}

Its chemical name is 2-(4-(2,2-dichlorocyclopropyl) phenoxy)-2-methylpropanoic acid and its mechanism of action is based on the activation of specific transcription factors called peroxisome proliferator-activated receptors (PPARs), which alter the transcription of several genes that encode the proteins that control lipoprotein metabolism (Bighetti et al., 2009; Bermúdez-Pirela et al., 2005; European Pharmacopeia, 2008). 


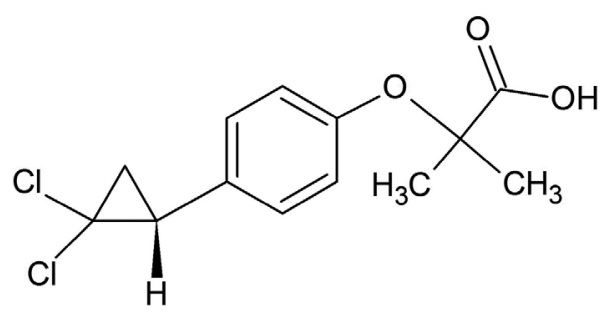

FIGURE 1 - Chemical structure of CPF (European Pharmacopeia 6th Ed, 2008).

CPF is commercially available as both tablets and capsules $(100 \mathrm{mg})$. An official method for the determination of this drug in oral formulations has not yet been described. Publications concerning the quantitative detection of $\mathrm{CPF}$ are relatively limited. However, there are studies describing the quantification of this drug in bulk and tablet forms by UV and visible spectrophotometry (Nascimento et al., 2011), high-performance thin-layer chromatography (HPTLC) (Jain et al., 2011) and LCUV (Jain et al., 2012); LC/MS/MS has also been used to quantify CPF in human plasma (Mendes et al., 2011). Several of these methods present methodologies based on techniques with high sensitivity and accuracy, but they require the use of hazardous and expensive chemicals, which make the process not only dangerous for the environment but also complex and time consuming. Moreover, there are no publications concerning UV spectrophotometric or stability-indicating LC methods for the quantification of CPF in capsules and tablets, and there is also no comparison study of the two methods.

The aim of this study was to develop and validate a simple stability-indicating LC method and a simple, fast and environmentally friendly UV spectrophotometric method for routine CPF analysis in tablets and capsules. The results obtained by these methods were statistically compared using two one-sided test (TOST). In addition, the reliability and feasibility of the results were evaluated, focusing on routine quality-control analysis.

\section{MATERIAL AND METHODS}

\section{Chemicals and reagents}

The CPF reference substance (Purity Grade Standards, Durham, USA) was kindly provided by Multilab (São Jerônimo, Brazil). The pharmaceutical formulations, capsules and tablets containing CPF were obtained commercially. The tablets were labelled as containing $100 \mathrm{mg}$ of CPF and the following inactive ingredients: starch, microcrystalline cellulose, silicon dioxide, hypromellose, lactose monohydrate, sodium lauryl sulfate, hydrogenated vegetable oil and purified water. The capsules were labelled as containing $100 \mathrm{mg}$ of $\mathrm{CPF}$ and the following inactive ingredients: magnesium stearate, silicon dioxide, microcrystalline cellulose and starch.

LC-grade acetonitrile was purchased from J. T. Baker (USA) and analytical-grade ethanol was obtained from Fmaia (Brazil). All of the chemicals used were of pharmaceutical or analytical grade. All aqueous solutions were prepared with purified water, obtained using Milli-Q apparatus (Millipore ${ }^{\circledR}$ ).

\section{LC method}

\section{Development}

The chromatographic conditions were optimised so that the performance of the assay was high. In order to find the most appropriate mobile phase for CPF determination, different solvent mixtures were analysed. Acetonitrile and methanol are organic solvents commonly used in LC; therefore, various mixtures of acetonitrile, methanol, water and $o$-phosphoric acid $(0.1 \% \mathrm{v} / \mathrm{v})$ were tested. Before mixing with an organic solvent, the $\mathrm{pH}$ value of the $o$-phosphoric acid was checked over the range $\mathrm{pH}$ 2.0-5.0. Different ratios of organic and aqueous phases were used to obtain the best analysis time and system suitability parameters. System suitability testing of the chromatographic system was performed before each validation run using five replicate injections of a standard solution. The number of theoretical plates, tailing factor, and injection repeatability were determined.

\section{Instrumentation and conditions}

The LC system consisted of a Shimadzu ${ }^{\circledR}$ instrument equipped with a diode array detector (DAD). The separation was performed using a Shimadzu ${ }^{\circledR}$ Shim-pack CLS-ODS (M) column (250 mm x $4.6 \mathrm{~mm}$, internal diameter: $5 \mu \mathrm{m}$ ) at room temperature, eluted at the flow

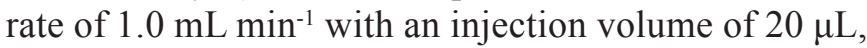
using an isocratic system. The mobile phase consisted of $o$-phosphoric acid $(0.1 \% \mathrm{v} / \mathrm{v})$ that was adjusted to $\mathrm{pH} 3.0$ using triethylamine $(10 \% \mathrm{v} / \mathrm{v})$ and acetonitrile $(35: 65 \mathrm{v} / \mathrm{v})$. The detection of CPF was achieved with a photodiode array detector at $233 \mathrm{~nm}$. The mobile phase was filtered through a $0.45 \mu \mathrm{m}$-thick nylon filter and degassed in an ultrasonic bath before use. The data obtained showed that the mobile phase was stable for at least $48 \mathrm{~h}$ when stored in a closed flask at room temperature.

\section{Calibration solutions}

A CPF stock solution with a concentration of 
$500 \mu \mathrm{g} \mathrm{mL}^{-1}$ was prepared in a volumetric flask by dissolving the CPF reference substance $(12.5 \mathrm{mg})$ in ethanol $(10 \mathrm{~mL})$ and making it up to a volume of $25 \mathrm{~mL}$ with purified water. Aliquots of 1, 1.5, 2, 2.5 and $3 \mathrm{~mL}$ were transferred to several volumetric flasks and diluted with purified water to produce final concentrations of 10 , $15,20,25$ and $30 \mu \mathrm{gL}^{-1}$.

\section{Sample preparation solutions}

The average weight of 20 tablets and 20 capsules was determined according to the Farmacopeia Brasileira (2010). The tablets were crushed to form a homogeneous powder and the contents of the capsules were homogenised. An accurately weighed amount of powder, equivalent to $12.5 \mathrm{mg}$ CPF, was transferred to a $25 \mathrm{~mL}$ volumetric flask, extracted with ethanol $(10 \mathrm{~mL})$, sonicated for $5 \mathrm{~min}$, and diluted to the $25 \mathrm{~mL}$ mark by adding water. An aliquot of this solution $(2 \mathrm{~mL})$ was transferred into a $50 \mathrm{~mL}$ volumetric flask, which was diluted with water to give a final concentration of $20 \mu \mathrm{g} \mathrm{mL}^{-1}$. The solutions were filtered through a $0.45 \mu \mathrm{m}$-thick nylon filter before LC analysis.

\section{UV spectrophotometric method}

\section{Development}

Different solvent media were investigated to develop a suitable UV spectrophotometric method for the analysis of CPF in formulations. In order to select the appropriate media, various criteria were used, including sensitivity of the method, ease of sample preparation, solubility of the drug, time consumption and cost of the solvents. The concentration and absorbance of CPF in the selected medium at the associated wavelengths were also determined.

\section{Instrumentation and conditions}

Spectral and absorbance measurements were performed on a Perkin Elmer Lambda $35 \mathrm{UV} / \mathrm{Vis}$ spectrophotometer, using quartz cells with a $1.0 \mathrm{~cm}$ path length and detection at $233 \mathrm{~nm}$.

\section{Calibration solutions}

A CPF stock solution with a concentration of $400 \mu \mathrm{g} \mathrm{mL}^{-1}$ was prepared in a volumetric flask by dissolving the CPF reference substance $(10 \mathrm{mg})$ in ethanol $(10 \mathrm{~mL})$ and making it up to a volume of $25 \mathrm{~mL}$ with purified water. Aliquots of 1, 1.5, 2, 2.5 and $3 \mathrm{~mL}$ were transferred to several volumetric flasks and diluted with purified water to produce final concentrations of $8,12,16$, 20 and $24 \mu \mathrm{g} \mathrm{mL}^{-1}$.

\section{Sample preparation for the solutions}

The average weight of 20 tablets and 20 capsules was determined according to the Farmacopeia Brasileira (2010). The tablets were crushed to form a homogeneous powder and the contents of the capsules were homogenised. An accurately weighed amount of powder, equivalent to $10 \mathrm{mg}$ CPF, was transferred to a $25 \mathrm{~mL}$ volumetric flask, extracted with ethanol $(10 \mathrm{~mL})$, sonicated for $5 \mathrm{~min}$, and diluted to the $25 \mathrm{~mL}$ mark by adding water. After filtration, an aliquot $(2 \mathrm{~mL})$ of this solution was transferred into a $50 \mathrm{~mL}$ volumetric flask and diluted with water to give a final concentration of $16 \mu \mathrm{g} \mathrm{mL} \mathrm{m}^{-1}$.

\section{Method validation}

The developed stability-indicating LC and UV spectrophotometric analytical methods were validated following ICH guidelines and USP requirements (International Conference on Harmonization, 2005; United States Pharmacopeia, 2012).

Linearity

The linearity was evaluated by linear regression analysis, which was calculated using the least-square regression method. The calibration curves were obtained with five concentrations for LC $\left(10-30 \mu \mathrm{g} \mathrm{mL}^{-1}\right)$ and UV methods $\left(8-24 \mu \mathrm{g} \mathrm{mL}^{-1}\right)$.

\section{Specificity}

The UV method was performed by preparing placebo solutions (an in-house mixture of tablet and capsules excipients) of the commercial products. In a separate study, a CPF reference substance with the same concentration was prepared and analysed. Each of the solutions was scanned from a wavelength of 400 to $200 \mathrm{~nm}$, and any interference in the absorbance was checked at all tested wavelengths.

In order to establish if the proposed LC method was in fact stability indicating, the pure CPF active pharmaceutical ingredient was stressed under different conditions as part of the forced degradation studies (Bakshi, Singh, 2002).

The CPF solutions for acid hydrolysis were prepared by dissolving the drug in a small volume of ethanol and diluting with aqueous hydrochloric acid to achieve a concentration of $1 \mathrm{mg} \mathrm{mL}^{-1}$. Acid hydrolysis was performed in $1 \mathrm{M} \mathrm{HCl}$ at $80^{\circ} \mathrm{C}$ for $4 \mathrm{~h}$ under reflux, after which the sample was cooled to room temperature and neutralised. The study under alkaline conditions was carried out in $1 \mathrm{M} \mathrm{NaOH}$ at $80^{\circ} \mathrm{C}$ for $7 \mathrm{~h}$ under reflux, after which the sample was cooled to room temperature 
and neutralised. An aliquot of each solution was diluted with water to give a final concentration of $20 \mu \mathrm{g} \mathrm{mL}^{-1}$. The stress degradation study with direct UV radiation (254 $\mathrm{nm}$ ) was performed by exposing the CPF solution in acetonitrile $\left(1 \mathrm{mg} \mathrm{mL}^{-1}\right)$ to the UV beam for $1.5 \mathrm{~h}$ at room temperature in a photostability chamber containing mirrors (Malesuik et al., 2009; Garcia et al., 2008). The distance between the lamp and the sample was $10 \mathrm{~cm}$. Afterwards, the solution was diluted to a concentration of $20 \mu \mathrm{g} \mathrm{mL}^{-1}$ with water. Samples subjected to identical conditions, but protected from light, were used as a control. The oxidative reaction was performed by dissolving $\mathrm{CPF}$ in a small volume of ethanol and then diluting with $30 \% \mathrm{H}_{2} \mathrm{O}_{2}$ $\left(1 \mathrm{mg} \mathrm{mL}^{-1}\right)$ at $80^{\circ} \mathrm{C}$ for $3 \mathrm{~h}$ under reflux. An aliquot of this solution was diluted in water to give a final concentration of $20 \mu \mathrm{g} \mathrm{mL}^{-1}$. To verify the stability of the CPF solution in anhydrous ethanol and water, the samples were prepared and analysed after they had been stored for 2, 6, 8 and $24 \mathrm{~h}$ at room temperature.

Peak purity tests were performed by the photodiode array detector, which were useful to show that the analyte chromatographic peak did not contain more than one substance.

\section{Precision}

The precision of the methods was evaluated by repeatability (intra-day precision) and intermediate precision (inter-day precision) tests. The repeatability was tested by assaying six samples at the same concentration $\left(20 \mu \mathrm{g} \mathrm{mL}^{-1}\right)$ throughout one day under consistent experimental conditions. The intermediate precision of the method was assessed by carrying out the analysis on three different days and with a different analyst performing the analysis in the same laboratory (betweenanalyst precision). Data were expressed as a function of the relative standard deviation (RSD\%) of a series of measurements.

\section{Accuracy}

The accuracy was determined by a recovery test, which consisted of adding aliquots of 1.0, 2.0 and $3.0 \mathrm{~mL}$ of the standard CPF solution (LC and UV stock solutions) to placebo solutions, which gave final concentrations of the reference standards as 10,20 and $30 \mu \mathrm{g} \mathrm{mL}^{-1}$ for LC and 8,16 and $24 \mu \mathrm{g} \mathrm{mL}^{-1}$ for UV tests. Each solution was prepared in triplicate.

\section{Robustness}

The robustness of the UV method was evaluated by analysing the same samples with small and deliberate modifications to the analytical conditions, such as changing the sonication time ( 3 and $7 \mathrm{~min}$ ), amount of added organic solvent ( 8 and $15 \mathrm{~mL}$ ethanol), manufacturer of the organic solvent and the stability of the CPF solutions for 24 hours at room temperature.

The robustness of the LC method was determined by analysing the same samples but with different method parameters, such as $\mathrm{pH}$ of the mobile phase ( \pm 0.2 units), the flow rate $\left( \pm 0.2 \mathrm{~mL} \mathrm{~min}^{-1}\right)$, proportion of each solvent in the mobile phase ( $\pm 5 \%$ organic phase) and the column (with the same specification, but acquired from a different supplier).

\section{RESULTS AND DISCUSSION}

\section{LC method development and optimisation}

The development of a LC method requires the careful consideration of the polarity of the analyte, stationary phase and mobile phase in order to obtain good separation within a reasonable time. Thus, the LC procedure was optimised to develop a stability-indicating method so that the degradation products from the drug could be resolved. The chromatographic conditions were chosen after testing different mobile phases with different proportions of organic and aqueous solvents (Figures 2 and 3). Acetonitrile and methanol are commonly used solvents in reverse-phase LC, because they have low UV cut-off points of 190 and $205 \mathrm{~nm}$, respectively. These solvents are miscible with aqueous solutions, so reversephase chromatography was performed with various mixtures of organic and aqueous solvents. During the development phase, acetonitrile and methanol were used in the mobile phase at different ratios, which resulted in an asymmetric peak with a large tailing factor $(T>2)$ and a very low retention time (Figure 2f). Exchanging methanol with water did not improve the separation, and the peak was still unresolved from the void volume (Figure 2e). To achieve a better separation, the aqueous phase and $\mathrm{pH}$ (in the range 2.0-5.0) were changed to optimise the CPF retention time to 6 min (Figures 2a, $b, c$ and d). Different ratios of the organic phase were analysed (Figure 3). Finally, a mobile phase containing $o$-phosphoric acid $(0.1 \% \mathrm{v} / \mathrm{v})$, adjusted to $\mathrm{pH} 3.0$ by adding triethylamine $(10 \% \mathrm{v} / \mathrm{v})$ and acetonitrile $(35: 65$ $\mathrm{v} / \mathrm{v}$ ), was adopted because of its low tailing factor, good capacity factor $\left(k^{\prime}\right)$ value, retention time and its ability to separate the degradation products from CPF with good peak parameters (Figure 5). The $\mathrm{pH}$ value of 3.0 was chosen because it showed a better peak profile compared those obtained at $\mathrm{pH} 4$ and 5 , and a $\mathrm{pH}$ value as low as 2.0 could damage the column. 


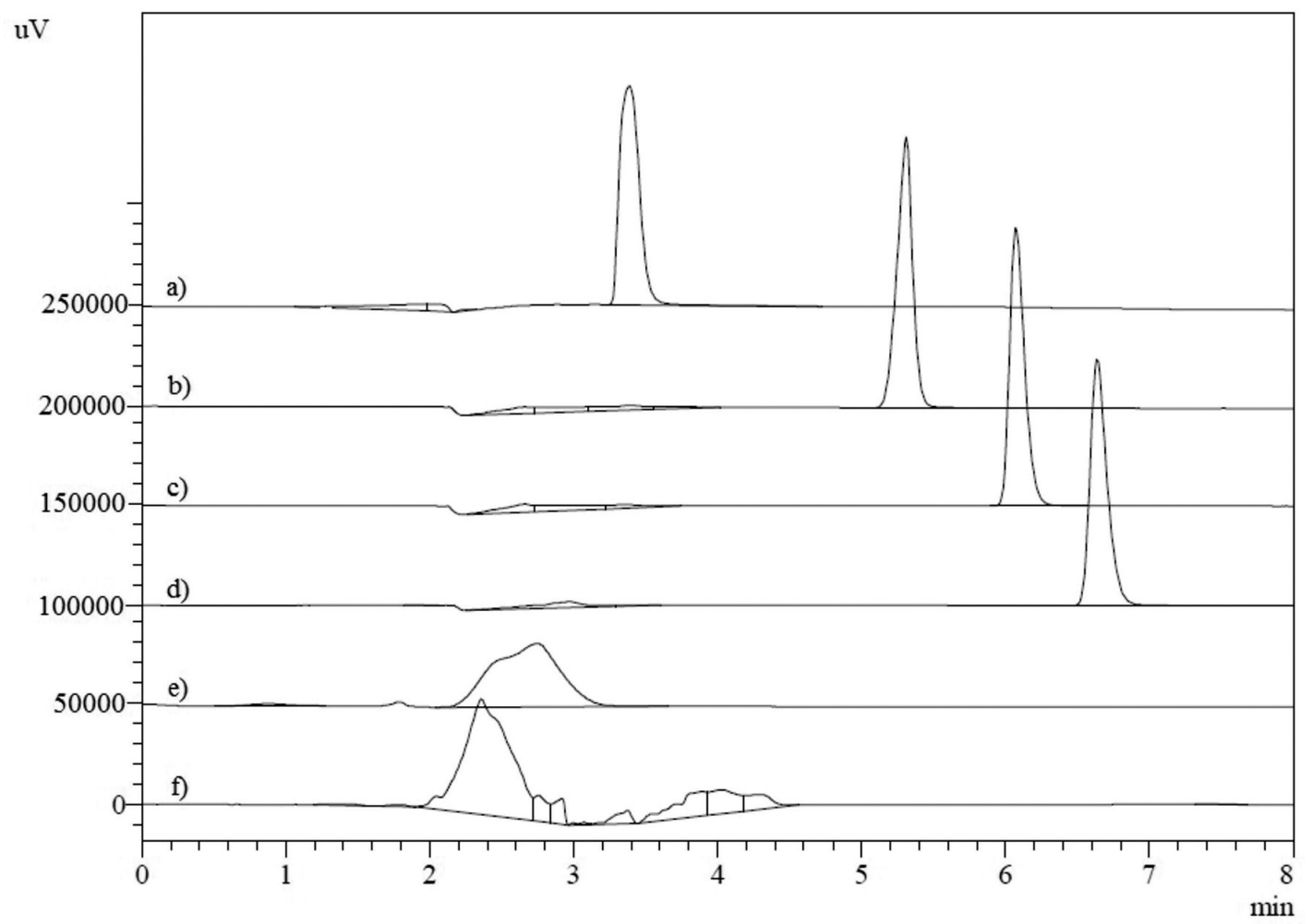

FIGURE 2. Chromatograms of CPF standard solution in tested mobile phases with $65 \%$ of ACN and $35 \%$ of a) $o$-phosphoric acid $0.1 \%(\mathrm{v} / \mathrm{v}) \mathrm{pH} 5.0, \mathrm{~b}) o$-phosphoric acid $0.1 \%(\mathrm{v} / \mathrm{v}) \mathrm{pH} 4.0$, c) $o$-phosphoric acid $0.1 \%(\mathrm{v} / \mathrm{v}) \mathrm{pH} 3.0$, d) $o$-phosphoric acid $0.1 \%$ $(\mathrm{v} / \mathrm{v}) \mathrm{pH} 2.0, \mathrm{e})$ purified water and f) methanol.

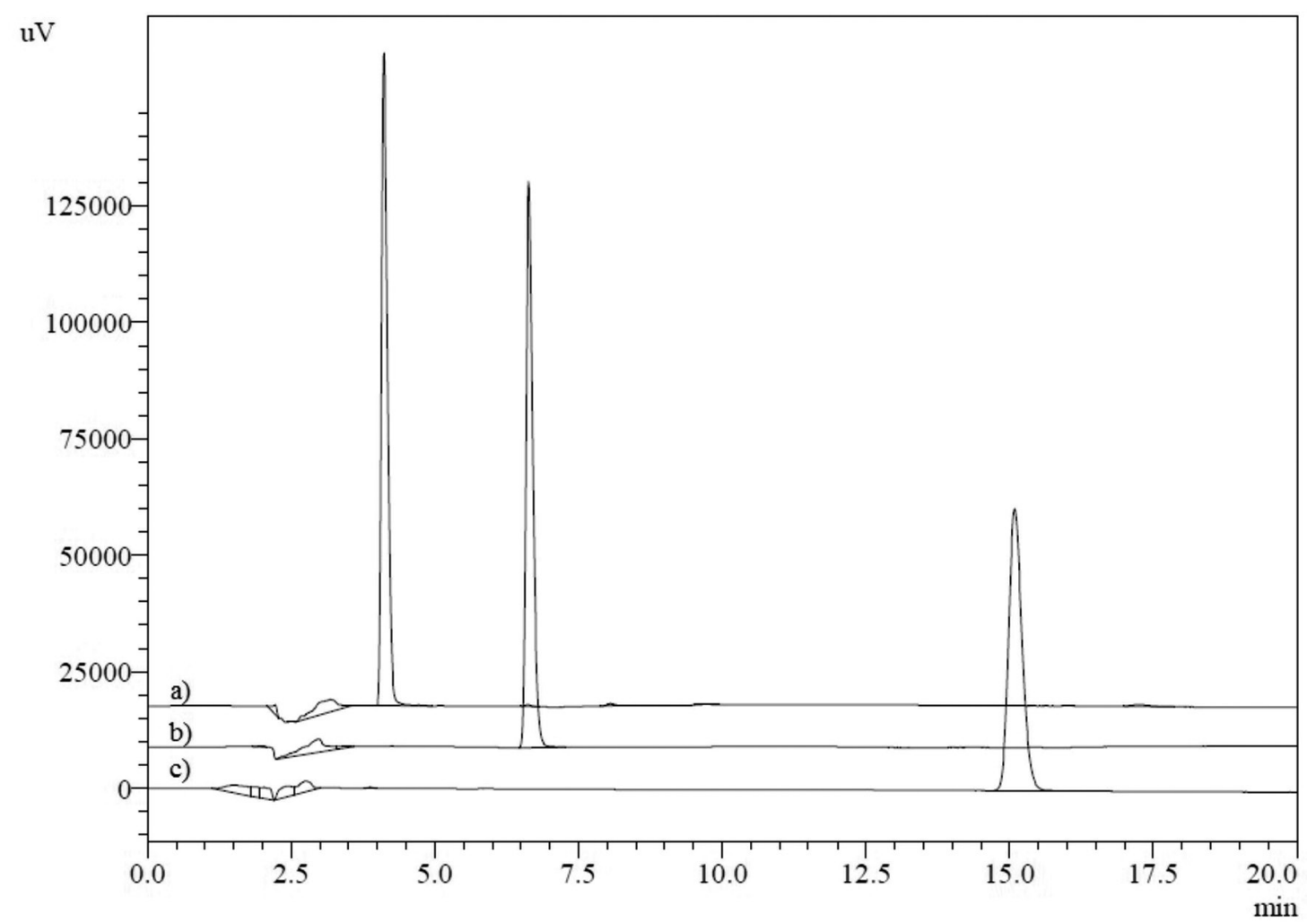

FIGURE 3. Chromatograms of CPF standard solution using as mobile phase $\mathrm{ACN}$ and $o$-phosphoric acid $0.1 \%(\mathrm{v} / \mathrm{v}) \mathrm{pH} 3.0 \mathrm{in}$ different ratios: a) 80:20; b) 65:35 and c) 50:50. 
A system suitability test of the chromatographic system was performed before each validation run. The system suitability test is an integrated part of the analytical method, which ascertains the suitability and effectiveness of the operating system. It was carried out to evaluate the reliability and reproducibility of the system for the analysis, using five replicate injections of a reference solution containing $20 \mu \mathrm{g} \mathrm{mL}^{-1} \mathrm{CPF}$. The approximate results gave the following results: theoretical plates $(N=6800)$, tailing factor or peak asymmetry $(T=1.2)$ and injection repeatability $(\mathrm{RSD} \%=0.36, n=5)$. The values for these parameters were satisfactory and in accordance with previously published data (Shabir, 2003). The tests ensure that the LC method generates reliable results. Thus, it was established that the LC system and procedure are capable of providing data of an acceptable quality.

\section{UV method development and optimisation}

In this study, different solvents were investigated to develop a suitable UV spectrophotometric method for the analysis of CPF in tablets and capsules. For the selection of diluents, the criteria employed were the sensitivity of the method, ease of sample preparation, time consumption and the solubility of the drug. CPF is practically insoluble in water, freely soluble in anhydrous ethanol and soluble in toluene (European Pharmacopeia, 2008). The use of acetonitrile, methanol or sodium hydroxide $(0.1$ and $0.01 \mathrm{M}$ ) as the diluent did not improve the sensitivity of the method. Thus, anhydrous ethanol was tested as the solvent, after addition of distilled water, in order to reduce organic solvent use. Absorption spectra were obtained by UV spectrophotometry in the range of $200-400 \mathrm{~nm}$ for the standard solutions in various solvents, and the overlap is shown in Figure 4.

The final decision to use ethanol and water as the analysis medium was based on various criteria, including the sensitivity of the method, cost, ease of preparation and the accuracy of the results.

\section{Method validation}

The validation ensures that the procedure is suitable for the intended purpose. The ICH and USP guidelines describe the analytical parameters that should be evaluated in a method validation. The method type and its intended use determine which parameters should be evaluated. It is the responsibility of the analyst to select the parameters that are considered to be relevant for each method (Ermer, 2001). The LC and UV spectrophotometric methods were validated for parameters such as linearity, specificity, precision, accuracy and robustness.

Linearity was established by least-squares linear regression analysis of the calibration curve. The regression equation for CPF was found by plotting the peak absorbance $(y)$ versus the sample concentration $(x)$. Correlation coefficients of 0.9999 (for the LC method) and 0.9998 (for the UV method) were considered to be

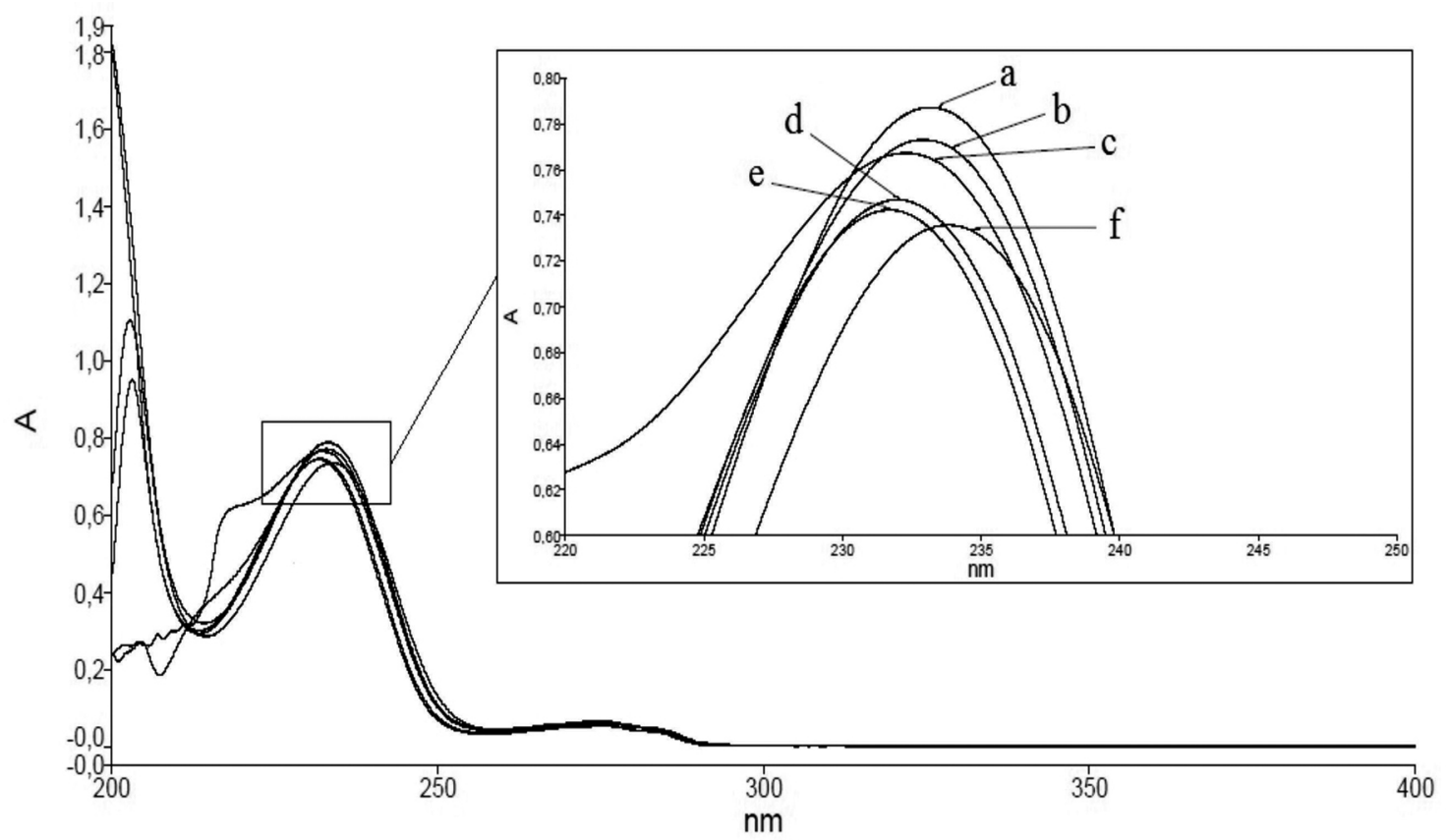

FIGURE 4. Overlap of the absorption spectra obtained by UV spectrophotometry in the range of 200-400 nm, of the standard solutions in: a) ethanol and water (diluent); b) sodium hydroxide $0.01 \mathrm{M}$; c) sodium hydroxide $0.1 \mathrm{M}$; d) methanol; e) acetonitrile and f) ethanol. 
highly significant. The validity of the assays was verified by means of ANOVA analysis (SAS 6.11 for windows, SAS Institute Inc. CARY, NC, USA), which demonstrated significant linear regression and no significant linearity deviation (Table I).

The specificity test demonstrated that there was no interference in the UV spectrophotometric determination of the drug. All solutions were scanned from 400 to $200 \mathrm{~nm}$ and checked for any change in the absorbance at the respective wavelengths. The UV spectrophotometric method proves to be specific for the determination of drugs present in tablet and capsule matrices, because there is no interference caused by excipients at the wavelength of the drug maximum absorption $\left(\lambda_{\max } 233\right)$. Forced degradation studies for the determination of the specificity of the direct UV method were not performed. Owing to specificity/selectivity limitations (e.g., in general terms, the degradation products present functional groups that absorb at the same wavelength of the intact drug), there are very few reports on the use of UV spectrophotometry for stability assays. However, there are some reports involving derivative spectroscopy that have been published recently (Abbas et al., 2012; Cielecka-Piontek, Lunzer, Jelińska, 2011). LC methods have taken precedence over conventional analysis methods; reverse-phase LC coupled with ionic suppression probably accounts for over $85 \%$ of stability-indicating methodologies for low-molecular- weight pharmaceutical entities. Other than the separation of multiple components, the advantage of LC methods is that they possess greater accuracy and sensitivity for even small quantities of degradation products (Bakshi, Singh, 2002; Shabir, 2003).

The forced degradation studies were conducted to evaluate the stability-indicating capability and selectivity of the proposed LC method using the CPF reference substance. Table II presents the extent of CPF degradation under both stress conditions and regular conditions, and Figure 5 shows the chromatograms of the untreated solution and the forced degradation samples.

It is important to note that although several degradation product peaks can be observed, the peak for $\mathrm{CPF}$ remains resolved. The chromatographic peak purity tool was applied to verify the CPF peak, showing that it was $100 \%$ pure in all cases, indicating the specificity of the proposed method. It was observed that the CPF peak presents appropriate resolution $(R \mathrm{~s}>2)$ and selectivity $(a>1)$ in relation to the degradation products. The results indicated that the method is indeed stability-indicating and that the drug can be evaluated both qualitatively and quantitatively in the presence of degradation products. The obtained results in the forced degradation studies show that the drug is susceptible to hydrolysis, oxidation and photolysis. Therefore, the stability of CPF in anhydrous ethanol and water was evaluated to verify if

TABLE I - Linearity data for UV and LC analyses

\begin{tabular}{lcc}
\hline & LC & UV \\
\hline Correlation coefficient & 0.9999 & 0.9998 \\
Linear equation & $y=49069 x-17753$ & $y=0.0462 x-0.0282$ \\
Linear regression* & $F_{\text {calculated }}=22746>F_{\text {critical }}=4.96$ & $F_{\text {calculated }}=17081>F_{\text {critical }}=4.96$ \\
Linearity deviation* & $F_{\text {calculated }}=1.4<F_{\text {critical }}=3.71$ & $F_{\text {calculated }}=2.4<F_{\text {critical }}=3.71$ \\
\hline
\end{tabular}

$* p<0.05$

TABLE II - Results of CPF stability under force degradation conditions and regular conditions

\begin{tabular}{lcc}
\hline Condition & Time (h) & Degradation (\%) \\
\hline Acid hydrolysis $(1 \mathrm{~N} \mathrm{HCl})$ & 4 & 60.47 \\
Basic hydrolysis $(1 \mathrm{M} \mathrm{NaOH})$ & 7 & 70.87 \\
Oxidation $\left(\mathrm{H}_{2} \mathrm{O}_{2}\right)$ & 3 & 60.14 \\
Photolysis & 1.5 & 55.64 \\
\hline & 2 & \\
Regular conditions (ethanol:water, room temperature) & 6 & no degradation \\
& 8 & \\
\hline
\end{tabular}



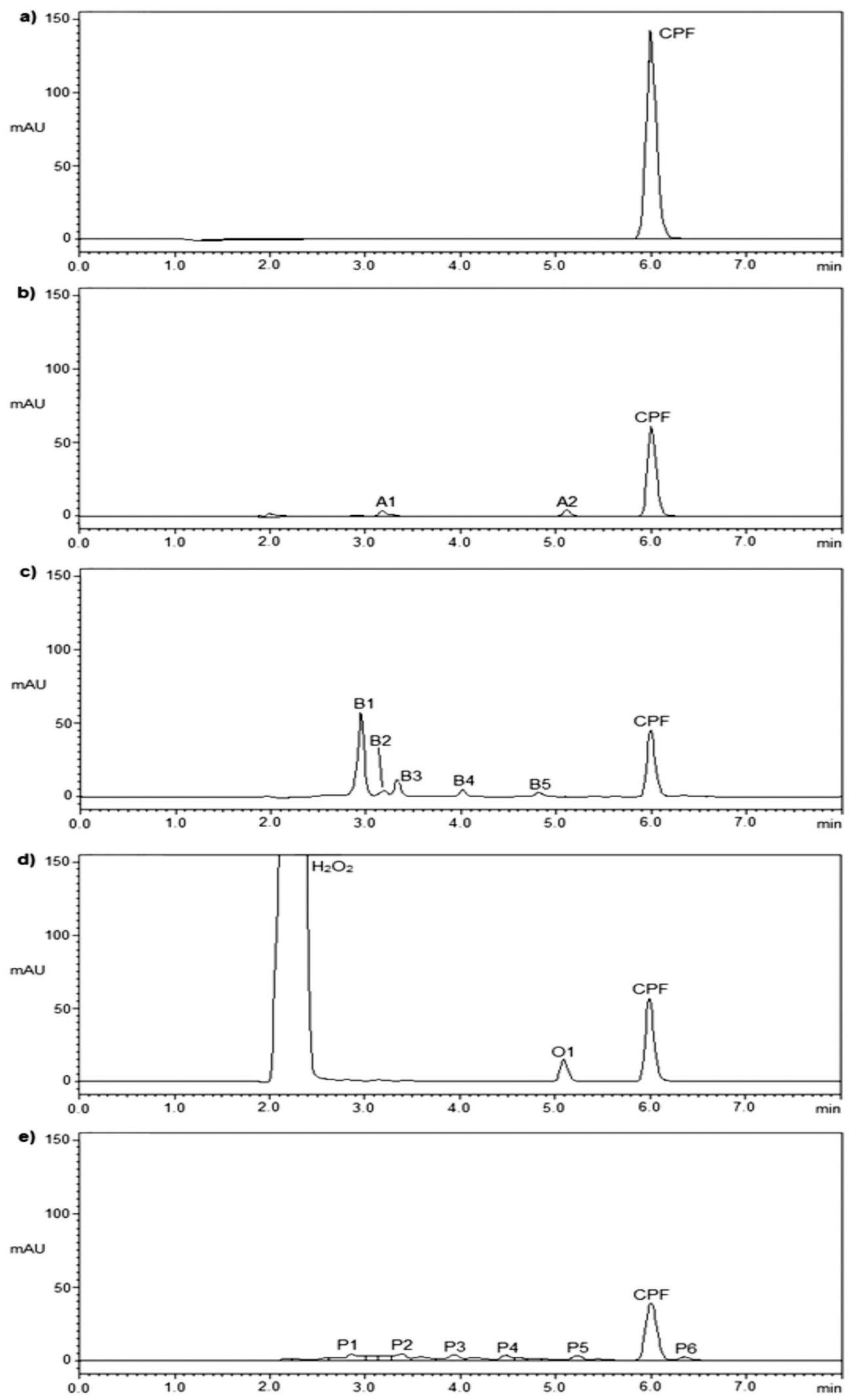

FIGURE 5 - a) Typical chromatogram for $20.0 \mu \mathrm{g} \mathrm{mL}^{-1} \mathrm{CPF}$ standard solution in the experimental selected conditions; b) chromatogram of $\mathrm{CPF}$ acid-degraded and degradation product $\mathrm{A} 1$ and $\mathrm{A} 2$; c) chromatogram of $\mathrm{CPF}$ basic-degraded and degradation products B1, B2, B3, B4 and B5; d) chromatogram of CPF oxidative-degraded and degradation product. 
any spontaneous degradation could occur between sample preparation and analysis. The data obtained showed that sample solutions were stable for at least $24 \mathrm{~h}$ when stored at room temperature (Table II).

The precision of the methods was determined by studying the repeatability and the intermediate precision. The experimental values obtained for the quantification of CPF in various samples are presented in Table III. The variability of the results was low, with $\mathrm{RSD} \%$ values less than 1.8 for repeatability and 1.4 for intermediate-precision analysis. The $\mathrm{RSD} \%$ values that were obtained for the

TABLE III - LC and UV assay precision results for CPF in tablets and capsules

\begin{tabular}{cccc}
\hline & & $\begin{array}{c}\text { Tablets } \\
\text { mean } \pm \text { RSD\% }\end{array}$ & $\begin{array}{c}\text { Capsules } \\
\text { mean } \pm \text { RSD\% }\end{array}$ \\
\hline \multirow{4}{*}{ LC } & 1 day $(n=6)$ & $102.54 \pm 1.20$ & $97.90 \pm 1.03$ \\
& 2 day $(n=6)$ & $100.73 \pm 0.74$ & $98.67 \pm 0.61$ \\
& 3 day $(n=6)$ & $99.62 \pm 1.76$ & $98.89 \pm 1.59$ \\
& Inter-day $^{\mathrm{a}}$ & $100.96 \pm 1.13$ & $98.49 \pm 0.43$ \\
\hline \multirow{3}{*}{ UV } & 1 day $(n=6)$ & $102.41 \pm 0.78$ & $99.83 \pm 0.56$ \\
& 2 day $(n=6)$ & $100.52 \pm 0.50$ & $96.84 \pm 0.83$ \\
& 3 day $(n=6)$ & $100.44 \pm 0.69$ & $97.32 \pm 0.25$ \\
& Inter-day ${ }^{\mathrm{a}}$ & $101.12 \pm 0.90$ & $98.00 \pm 1.31$ \\
\hline
\end{tabular}

${ }^{a}$ Data expressed as the mean of 3 days. analytical methods were within the acceptable range, indicating that these methods have great repeatability and intermediate precision.

With regards to the accuracy of the two methods, the excellent mean percentage recovery values and their low RSD\% $(\leq 1.5)$ were found to be satisfactory. At each CPF concentration, three determinations were performed for each method. The mean recovery for the UV spectrophotometric method was $99.15 \%(\mathrm{RSD} \%=0.81)$ and $102.59 \%(\mathrm{RSD} \%=0.77)$ for the tablets and capsules, respectively, and the LC mean recovery was $100.54 \%$ $(\mathrm{RSD} \%=1.15)$ and $99.64 \%(\mathrm{RSD} \%=1.44)$. These results revealed that any small change in drug concentration in these solutions could be accurately determined by the proposed analytical methods.

The robustness of each method was demonstrated by small variations in the analytical conditions, which are cited above. The obtained results (Table IV) show that there are no important effects on the analysis, confirming the robustness of the proposed methods.

\section{Comparison of the UV spectrophotometric method and the LC method}

The analytical methods were compared using statistical analysis. The two one-sided test (TOST) (XLSTAT Version 2014.1.07 for windows) was used as an equivalence test to compare the experimental values

TABLE IV - Experimental values for the robustness testing, obtained from UV and LC analysis of CPF in tablets and capsules

\begin{tabular}{|c|c|c|c|}
\hline & \multirow[b]{2}{*}{ Analysis conditions } & \multicolumn{2}{|c|}{ CPF content } \\
\hline & & $\begin{array}{c}\text { Tablets } \\
\text { mean* } \pm \text { RSD } \% \\
\end{array}$ & $\begin{array}{c}\text { Capsules } \\
\text { mean* } \pm \text { RSD } \%\end{array}$ \\
\hline \multirow{9}{*}{$\mathbf{L C}$} & Column (different supplier) & $98.75 \pm 0.67$ & $95.78 \pm 0.58$ \\
\hline & Temperature $30^{\circ} \mathrm{C}$ & $102.91 \pm 2.28$ & $96.87 \pm 0.22$ \\
\hline & Flow rate $0.8 \mathrm{~mL} \mathrm{~min}^{-1}$ & $98.86 \pm 0.59$ & $95.72 \pm 0.62$ \\
\hline & Flow rate $1.2 \mathrm{~mL} \mathrm{~min}^{-1}$ & $101.28 \pm 1.12$ & $97.76 \pm 0.87$ \\
\hline & $70 \%$ acetonitrile & $99.16 \pm 0.38$ & $95.43 \pm 0.83$ \\
\hline & $60 \%$ acetonitrile & $99.16 \pm 0.38$ & $95.28 \pm 0.94$ \\
\hline & pH 2.7 & $99.26 \pm 0.31$ & $95.43 \pm 0.83$ \\
\hline & pH 3.3 & $98.72 \pm 0.69$ & $94.93 \pm 1.20$ \\
\hline & Regular conditions & $99.70 \pm 0.86$ & $96.57 \pm 0.77$ \\
\hline \multirow{7}{*}{$\mathbf{U V}$} & Addition of $8 \mathrm{~mL}$ ethanol & $100.27 \pm 0.90$ & $98.65 \pm 0.42$ \\
\hline & Addition of $15 \mathrm{~mL}$ ethanol & $99.92 \pm 1.70$ & $99.99 \pm 0.53$ \\
\hline & Sonication for $3 \mathrm{~min}$ & $101.18 \pm 0.30$ & $98.27 \pm 0.43$ \\
\hline & Sonication for $7 \mathrm{~min}$ & $101.37 \pm 0.37$ & $99.06 \pm 0.56$ \\
\hline & $24 \mathrm{~h}$ at room temperature $\left(25^{\circ} \mathrm{C}\right)$ & $101.71 \pm 0.48$ & $98.58 \pm 0.47$ \\
\hline & Different ethanol manufacturer & $100.32 \pm 0.54$ & $99.69 \pm 0.73$ \\
\hline & Regular conditions & $100.04 \pm 0.71$ & $99.00 \pm 0.16$ \\
\hline
\end{tabular}


TABLE V - TOST results for the comparison of the LC and UV methods

\begin{tabular}{|c|c|c|c|}
\hline \multicolumn{2}{|c|}{ CPF in tablets } & \multicolumn{2}{|c|}{ CPF in capsules } \\
\hline Test & Value & Test & Value \\
\hline Lower bound (TOST) & -2.000 & Lower bound (TOST) & -2.000 \\
\hline Lower bound (90\%) & -0.703 & Lower bound (90\%) & -0.296 \\
\hline Upper bound (90\%) & 1.021 & Upper bound (90\%) & 1.276 \\
\hline Upper bound (TOST) & 2.000 & Upper bound (TOST) & 2.000 \\
\hline Test interpretation & equivalent & Test interpretation & equivalent \\
\hline
\end{tabular}

$\alpha=0.05$

(Table III) that were obtained from the analysis of samples with the two different methods. Equivalence was tested by determining $90 \%$ confidence intervals, based on the experimental values obtained in the precision test. We could accept the null hypothesis and declare that the analytical methods were equivalent when the $90 \%$ confidence interval for the difference was completely contained within the defined range considered to be scientifically trivial $( \pm \Delta)$. We defined $\Delta=2$ as an appropriate range for the equivalence testing, based on the specifications of the precision test $\left(\mathrm{RSD}_{0} \leq 2\right)$. TOST was applied and showed equivalence, at the 5\% significance level, between the experimental values obtained in the sample analysis when using the different methods, as shown in Table V.

The developed and validated methods provide similar results for CPF quantitation, and can be applied directly and easily to oral preparations of the pharmaceutical drug. The direct UV method is a useful tool for routine analysis, but when it is necessary to prove the stability and to identify and/or quantify the degradation products, the chromatographic methods are a better choice, owing to the stability-indicating capability and superior sensitivity and selectivity. However, the time and cost of the analyses cannot be disregarded in routine analysis, and the spectrophotometric method is clearly less expensive, easier to use, requires a shorter analysis time and generates fewer residues.

\section{CONCLUSION}

This study presents two simple methods for the determination and quantification of CPF in pharmaceutical formulations. The methods were validated, showing satisfactory data for all of the tested parameters. There were no significant differences between the stabilityindicating LC and UV spectrophotometric methods. As both of these methods are fast and simple, they may be successfully applied to quality-control analyses, with the aim of quantifying and identifying CPF in pharmaceutical products.

\section{ACKNOWLEDGMENTS}

The authors thank CAPES and CNPq (Brazil) for the financial support.

\section{REFERENCES}

ABBAS, S. S.; ELGHOBASHY, M. R.; SHOKRY, R. F.; BEBAWY, L. I. Stability indicating HPLC and spectrophotometric methods for the determination of bupropion hydrochloride in the presence of its alkaline degradates and related impurity. Bull. Fac. Pharm, Cairo Univ., v.50, n.1, p.49-59, 2012.

BAKSHI, M.; SINGH, S. Development of validated stabilityindicating assay methods - critical review. J. Pharm. Biomed., v.28, p. 1011-1040, 2002.

BIGHETTI, E. J. B.; PATRÍCIO, P. R.; CASQUERO, A. C.; BERTI, J. A.; OLIVEIRA, H. C. F. Ciprofibrate increases cholesteryl ester transfer protein gene expression and the indirect reverse cholesterol transport to the liver. Lipids Health Dis., v.8, n.1, p.50-58, 2009.

BERMÚDEZ-PIRELA, V.; SOUKI, A.; CANO-PONDE, C.; BERMÚDEZ-ARIAS, F.; MENGUAL-MORENO, E.; LEAL-GONZALEZ, E.; LEMUS-ANTEPAZ, M.; CABRERA, M. B.; AMELL, D. A.; LEAL, P. N.; CANOPEÑALOZA, R.; PUCHE-MEDINA, G.; RAMIREZ, I.; CONTRERAS, F.; VELASCO, M. Ciprofibrate diminishes NON-HDLc and improves HDLc in patients with Frederickson type IV dyslipidemia phenotype. $A V F T$, v.24, n.2, p.10-16, 2005. 
CIELECKA-PIONTEK, J.; LUNZER, A.; JELIŃSKA, A. Stability-indicating derivative spectrophotometry method for the determination of biapenem in the presence of its degradation products. Cent. Eur. J. Chem, v.9, n.1, p.3540, 2011.

FARMACOPEIA BRASILEIRA. 5.ed. Brasília: ANVISA, 2010. Available at: <http://www.anvisa.gov.br/hotsite/ cd_farmacopeia/index.htm >. Accessed on: 10 Jan 2012.

ERMER, J. Validation in pharmaceutical analysis. Part I: An integrated approach. J. Pharm. Biomed., v.24, n.5-6, p.755767, 2001.

European Pharmacopeia. 6.ed. Strasbourg: Council of Europe, 2008. p.1547-1548.

GARCIA, C. V.; NUDELMAN, N. S.; STEPPE, M.; SCHAPOVAL, E. E. S. Structural Elucidation of Photodegradation Products of Rabeprazole Sodium. $J$. Pharm.. Biomed., v.46, n.1, p.88-93, 2008.

ICH HARMONISED TRIPARTITE GUIDELINE. Validation of analytical procedures: text and methodology Q2(R1). Available at: < http://www.ich.org/fileadmin/Public_Web_ Site/ICH_Products/Guidelines/Quality/Q2_R1/Step4/ Q2_R1_Guideline.pdf>. 2005. Accessed on: 18 Jun 2012.

JAIN, P. S.; JIVANI, H. N.; KHATAL, R. N.; SURANA, S. J. Development and validation of stability-indicating high-performance thin-layer chromatography method for estimation of ciprofibrate in bulk and in pharmaceutical formulation. Acta Chromatogr., v.23, n.3, p.469-482, 2011.
JAIN, P. S.; JIVANI, H. N.; KHATAL, R. N.; SURANA, S. J. Stability-indicating HPLC determination of ciprofibrate in bulk drug and pharmaceutical dosage form. Chem. Ind. Chem. Eng. Q., v.18, p.95-101, 2012.

MALESUIK, M. D.; PAIM, C. S.; GONCALVES, H. M.; SCHAPOVAL, E. E. S.; STEPPE, M. LC: Analysis of photodegradation kinetics of nitazoxanide in pharmaceutical formulations. J. Chromatogr. Sci., v.47, p.745-748, 2009.

MENDES, F. D.; CHEN, L. S.; BORGES, A.; BABADÓPULOS, T.; ILHA, J. O.; ALKHARFY, K. M.; MENDES, G. D.; DE NUCCI, G. Ciprofibrate quantification in human plasma by high-performance liquid chromatography coupled with electrospray tandem mass spectrometry for pharmacokinetic studies. J. Chromatogr. B., v.879, p.2361-2368, 2011.

NASCIMENTO, G. N. L.; ROSA, D. L.; NISHIJO, H.; AVERSIFERREIRA, T. A. Validation of a spectrophotometric method to determine ciprofibrate content in tablets. Braz. J. Pharm. Sci., v.47, n.1, p.23-29, 2011.

SHABIR, G. A. Validation of high-performance liquid chromatography methods for pharmaceutical analysis. Understanding the differences and similarities between validation requirements of the US Food and Drug Administration, the US Pharmacopeia and the International Conference on Harmonization. J. Chromatogr. A., v.987, p.57-66, 2003.

UNITED States Pharmacopoeia. 35.ed. Rockville: United States Pharmacopoeia Convention, 2012. 2879 p.

Received for publication on $05^{\text {th }}$ December 2013 Accepted for publication on $14^{\text {th }}$ April 2014 
